\title{
Assessing Readiness for Self-Directed Learning among College Students in the Provision of Higher Learning Institution
}

\author{
Norshidah Nordin*1, Nurhazwani Abd Halim² , Melissa Malik ${ }^{3}$ \\ ${ }^{123}$ Faculty of Education Universiti Teknologi MARA, Kampus Seksyen 17, 40200, Shah Alam
}

\begin{abstract}

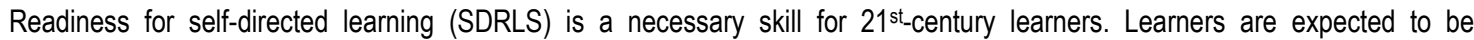
responsible for their own learning. However, to what extend Malaysian students are ready to facilitate their own learning or are they still being spoon-fed? This study was intended to assess SDLRS among college students. It utilized a survey method research design. There were 136 diploma students participated in this study. The finding revealed that respondents' levels of SDRLS were high. There was significant difference between SDRLS and gender but no significant differences between academic achievement and hometown. The discussion addresses implications to educators in designing instructional strategies

(C) 2016. The Authors. Published for AMER ABRA by e-International Publishing House, Ltd., UK. This is an open access article under the CC BY-NC-ND license (http://creativecommons.org/licenses/by-nc-nd/4.0/).

Peer-review under responsibility of AMER (Association of Malaysian Environment-Behaviour Researchers), ABRA (Association of Behavioural Researchers on Asians) and CE-Bs (Centre for Environment-Behaviour Studies), Faculty of Architecture, Planning \& Surveying, Universiti Teknologi MARA, Malaysia.
\end{abstract}

Keywords: innovation, self-directed learning, readiness, $21^{\text {st }}$-century learners

\section{Introduction}

Malaysian higher learning institutions are recognizing the importance of self-directed learning (SDL) as a necessary skill for 21 st-century learners. In fact, in the 21 st-century learning where innovation and creativity have been emphasized in the classroom context, educators become the facilitators of students' learning and creators of productive classroom environment in which students can develop generic skills such as critical thinking, creative thinking, and innovative thoughts which they will need at their workplace. Besides, Teo et al (2010) noted that new development in educational landscapes such as online web-based learning, and internet-connected mobile device have placed high expectation on learners to be more responsible and resourceful in their own learning. For example, according to Fahnoe and Mishra (2013), the used of flipped classroom has attracted interest in the value of SDL among elementary school students where they must be able to deal with resources, exhibit independence

\footnotetext{
* Corresponding author. Tel.:

E-mail address: shidah147@gmail.com
}

2398-4287 @ 2016. The Authors. Published for AMER ABRA by e-International Publishing House, Ltd., UK. This is an open access article under the CC BY-NC-ND license (http://creativecommons.org/licenses/by-nc-nd/4.0/).

Peer-review under responsibility of AMER (Association of Malaysian Environment-Behaviour Researchers), ABRA (Association of Behavioural Researchers on Asians) and cE-Bs (Centre for Environment-Behaviour Studies), Faculty of Architecture, Planning \& Surveying, Universiti Teknologi MARA, Malaysia.

DOI: http://dx.doi.org/10.21834/e-bpj.v1i3.352 
and be self-discipline in order to be successful in their academic performance. Thus, the advancements in technologies can help learners to access to a plethora of materials through the internet in which it can enhance learners' learning processes.

The above mentioned studies have portrayed the significance of SDL from different perspectives, however, to what extend Malaysian students are ready to facilitate their own learning or are they still being spoon-fed? This is supported by previous studies which noted that Asian students were rote or surface learners (Robertson, Line, Jones \& Thomas, 2000). In this context, Freire (1993) claimed that this type of learning as "banking education", which indicated that learners are vessels or containers to be filled by teachers' narration. A study done by Thanh Thi Hong Pham \& Renshaw (2013) found that Asian teachers were unwilling to empower students to engage in the learning process as active and independent learners. They also found that both teachers and students discard student-centered learning activities as a tool to promote creativity and higher order thinking. According to Boyer (1987), spoon-feeding through heavy lectures or teacher-centered approach have for many years been the traditional method of teaching in the classroom. Siti Akmal Abu Samad et al (2009) asserted that spoon-feeding may also be referred to as the behavioral action that indulges learners' thinking and compromises self-development. Thus, they claimed that pedagogically, this behavior may hinder independent learning and even block learners' creativity and innovative thoughts. For instance, past studies have shown that college students were being spoonfed to pass examinations instead of being encouraged to develop knowledge and understanding (Robertson, Line, Jones \& Thomas, 2000). Hence, when they enrolled at the university they were less independent and expected more from educators. Besides, there were also instances that educators encountered their students who never did their homework, relied heavily on teachers' note, and played passive roles in class. As a result, the learners were not able to connect new information to previous knowledge or make sense of the new information in the light of real experiences (Shepard, 2000). Therefore, due to lack of critical thinking skills, problem-solving abilities and communication skills may limit learners to understand today's global perspectives and demands.

Nevertheless, to address those issues, much effort have been taken by higher learning institutions to improve pedagogy and students' learning so that they could remain relevant and competitive especially preparing them for the working world. Flannagan (2007) said that the issue encountered by educators today is not teaching learner to get good marks, but more importantly, is to train them for life beyond the classroom. Hence, self-directed learning becomes one of the vital learning approaches in educational discourses. However, most of the studies were done on SDL focused on adult learners and lacked empirical studies were carried out among younger learners (Fahnoe and Mishra, 2013). Furthermore, SDL is viewed as an effective mode of learning for college students (Prabjandee \& Inthachot, 2013) but empirical evidence on the assessing college students' readiness in SDL is still lacking especially in the local context. It is pertinent for the educators to recognize their students' SDL readiness as they could maximize learning opportunity and create meaningful learning experiences for their learners.

\section{Objectives of the study}

- To identify the level readiness for self-directed learning among the college students

- To examine the significant difference between readiness for self-directed learning and gender among the college students

- To examine the significant difference between readiness for self- directed learning and hometown among the college students

- To examine the association between readiness self-directed learning and level academic achievement among the college students

\section{Literature review}

Understanding the concept of self-directed learning (SDL)

Self-directed learning has been widely reviewed in literature especially in the area of Adult Education since early of 
the century. However, researchers asserted that the concept of SDL is vague and intangible (Benson, 2011; $\mathrm{Ng}$, 2008). Despite the confusion, many similar terms such as self-direction in learning, self-instructed learning, autonomous learning, self-planned learning, self-regulated learning, self-managed learning, self-education, and independent learning have been used interchangeably by many researchers (Thorpe, 2005). Tough (1967) defined SDL as a self-teaching project where learner determines his/her own goal, set to achieve it, seek relevant resources, plan learning strategies, and motivated and able to learn independently. Conversely, Gibbsons (2002) suggested that SDL is any form of knowledge, skills, and self-development that learner achieved by his /her efforts using methods or strategies that can enhance learning.

Researchers emphasized that SDL plays an important part in the development of adult learning (Bolhuis, 2003; Brockett \& Hiemstra, 1991; Merriam, 2001). Brookfield, (1984) wrote that Lindeman (1926) highlighted in his book that adult learners are goal-oriented and their vast experiences motivate them to choose the path for their own learning. Nevertheless, it was Knowles (1975) who first coined the termed self-directed learning and defined it as a learning process where learners take responsibility for their own learning, formulate their learning goals, choose their learning resources, use appropriate learning strategies, and evaluate their own learning outcomes. For more than five decades, Knowles (1975) asserted that self-directed learning approach would become one of the important survival skills. Indeed, this kind of proactive approach has been emphasized within higher education curriculum (Hambur, Rowe, \& Tu Luc, 2002). Knowles (1975) asserted that there was a distinction between traditional pedagogy and adult learning needs. In this context, Knowles (1975) introduced the concept of andragogy, which refers as the art of teaching adult learners. The concept of andragogy was based on certain assumptions about the adult learners' characteristics which include life experiences, self-concept, readiness to learn, and orientation to learning.

Hiemstra (2003) and Orddi (1987) indicated that SDL can be conceptualized from three different perspectives, that are, as a process, characteristics and a combination of the two perspectives. According to Brockett and Hiemstra (1991), the process perspective suggested that the learners are responsible for planning, implementing and evaluating their own learning experiences. On the other hand, characteristics perspective focuses on the attribute or personal characteristics of the learners. In this sense, SDL refers to learners' self-efficacy, motivation, goal orientation, strategy to achieve goals, and preparation towards new challenges (Garrison, 1997). The third perspective was referred to the combination of two concepts that integrate instructional process method and personality characteristics. Nevertheless, Long (1989) highlighted that major theories and principles underlining the concepts SDL came from the disciplines of sociology, pedagogy, and psychology. Long $(1989,1990,1991)$ focused on the psychological aspect of SDL. He claimed that successful self-directed learner shall depend on the following traits that include self-confidence, self-awareness, reflective, goal orientation and systematic procedures. He also stressed on the role of learner characteristics within the SDL process. He asserted that personal characteristics are important indicators whether learner will engage with learning structures or otherwise. Besides, literature noted that psychological variables such as interest, personality, emotional stability, independence, super-ego strength, sensitivity, and conscientiousness may have direct influence on college students SDL (Lounsbury, Levy, Park, Gibson, \& Smith, 2009, De Bruin, 2007), while social and demography variables may have indirect impact on SDL ( Oliveira \& Simoes, 2006). Other interesting studies were done by Ponton, Derrick, \& Paul (2005) found that personality traits explain the content of self-directed learning. Conversely, Roberson and Merriam (2005) asserted that developmental processes of influencing SDL are associated with personality traits. Roberson and Merian (2005) in their studies found that the developmental process of influencing adult SDL include factors such as physiological changes, retirement, inspiration and new generation.

Nonetheless, according to Adenuga (1989), since much research effort has been geared toward the measurement and definition of self-directedness, hence the concept of self-directed learning readiness developed in the context of self-directed learning is most relevant. Parallel, Merriam et al (2007) suggested that self-directed learning readiness $(\mathrm{SDLR})$ is by far the most frequently used assessment. According to literature, there are two leading instruments used to measure the ability and readiness for SDL (Harvey, Rothman, and Frecker $(2003,2006)$ and Pachnowski and Jurczyk (2000). The first instrument, SDLRS (Guglielmino \& Guglielmino, 2008) was developed by Guglielmino and is widely used in educational research to measure SDL readiness. It has 58-items Likert scale with eight subdimension scales, namely, love of learning; self-concept, independent learner; tolerance of risk, ambiguity, and 
complexity in learning; creativity; view of learning as a lifelong, beneficial process; initiative in learning; selfunderstanding; and acceptance of responsibility for one's own learning. Another useful instrument to measure SDL readiness was termed as Oddi Continuing Learning Inventory (OCLI) developed by Oddi (1984). Oddi's (1986) thought on SDL was conceptualized based on personality characteristic, rather than a process or the combination of the two. Hence, the instrument was designed based on personality traits that she believed to SDL were proactive drive versus reactive drive; cognitive openness versus defensiveness and commitment to learning versus apathy or aversion to learning. However, this study utilized the instrument developed by Guglielmino (1977) as it has been long established with high validity and reliability scales. Past studies contended that the matching teaching delivery with SDL readiness could provide an opportunity for learning (Guglielmino 1977, O'Kell 1988, Grow 1991). Besides, Guglielmino (2013) claimed that it is pertinent to establish SDL readiness because an appropriate intervention can enhance learners' readiness for self-directed learning. Guglielmino (2013) further elaborates that individual's level of readiness can be demonstrated through individual personal characteristics such attitude, values, and abilities. SDL readiness naturally exists along a continuum ranging from high levels to moderate and some showing a strong preference for direction instruction. In this context, Osman (2013) found that SDL is a skill which can be improved through learning activities catered to increase the readiness level of SDL. Therefore, he emphasized that ensuring learners on a good level of SDL in early stages can allow them to prepare for the working life later.

\section{The association between self-directed learning and demographic variables}

The literature showed that there were relationships between SDL and demographic variables such as gender, age, races, urban/rural, educational level, marital status and academic performance (Shulman, 1994; Fontaine, 1996; Morris, 1995; Freed, 1997; Uhland 1995). However, the result of these studies was inconsistent. Shulman (1994) found that there was a significant relationship between SDL assessed using OCLI and gender. In addition, Fontaine (1996) revealed that marital status is a predictor of an older adult's frequency of participating in SDL. In a study done by Osman (2015) on first semester students of Engineering and Built Environment faculty, showed the median female SDLR scores are clearly higher than male respondent. The result indicated that $93.5 \%$ of female students were prepared for SDL and $46 \%$ of male respondents were expected to have no problems to practice SDL. In this sense, Hayes and Flannery (2000) suggested that women learning approaches may differ from their male counterparts, relying on different perspectives such as emotions, self-identity roles, the expectation for what kinds of learning or engagement is suited for them. On the other hand, Grover and Miller (2014) found that women select different self-directed learning tools than men in community organizations. Hence, they claimed that these differences might provide significant sociological trends about self-directedness and the desire to learn. However, in the studies done by Carson (2012) and Roberson and Merian (2005), there was no significant difference between gender and SDL.

Several studies also indicated that there was an association between self-directed learning and academic performance (Cazana \& Schiopca, 2014; Chou \& Chen, 2008); Lounsbury, Levy, Park, Gibson, \& Smith, 2009). Parallel, studies were done by Chou \& Chen (2008) revealed that there was a positive correlation between selfdirected learning and GPA and also course grade. The studies also reported that self-regulated learning predicts academic success. Literature also showed that self-directed learning was also a predictor of academic performance in traditional learning settings or non-web-based distance learning (Hsu \& Shiue, 2005). In a longitudinal study conducted by Slaughter (2009) among pharmacy preparation program students, the result revealed that students with above average SDLRS scores performed better than those with lower scores. Those students with high SDLR were found to be able to graduate on time and have lower exclusion rates. Nevertheless, there was no significant relationship between SDL and academic performance in a study done by Francis \& Flanigan (2012).

\section{Methodology}

A survey method using cross-sectional research design was utilized in this study. The instrument measuring selfdirected learning readiness was adapted from the self-directed learning readiness scale which was developed by 
Guglielmino (1977). The instrument was designed to assess individual attitudes, values, skills and personality characteristics supportive of self-direction in learning. It consists of 58 statements with five-point Likert scale, ranging from 1 (strongly disagree) to 5 (strongly agree) to which the respondents need to responds whether the statement describes them. SDLRS scale was developed to measure the complex of attitudes, skills and characteristics that encompass learner's current level of readiness to manage his/her learning process. Sample questions such as, "I know what I want to learn"; "In a classroom, I expect the teacher to tell all class members exactly what to do at all times", "No one but me is truly responsible for what I learn" were used to measure the level of leaner's readiness towards learning. According to Guglielmino (1977) learners with low SDLRS usually refer to a structured learning (i.e. lectures in a face-to-face classroom environment). While, learners with moderate or average SDLRS scores are likely to be more independent and comfortable handling and identifying their learning needs. On the other hands, high level of SLDRS indicated that learners prefer their own learning, plan and implement their learning process. Nevertheless, a learner with moderate or high SDLRS does not mean they never choose to be in a structured learning environment. There were about 170 respondents from one of the private higher learning institution participated in this study. However, a total of about 136 completed and returned the questionnaires. Therefore, the response rate was $66.8 \%$. These students have undertaken a Diploma in TESL program. The majority of these students were female $(80.3 \%)$ as compared to male $(18.7 \%)$ counterparts. Simple calculations like frequencies, percentages, mean and standard deviation and cross tabulation were used to describe the data. A cross tabulation is a joint frequency distribution of cases based on two or more categorical variables. Besides, TTest and ANOVA were used to analyze for inferential data. The data were analyzed by using Statistical Package for the Social Science (SPPS) Version 18.

\section{Findings}

Research objective 1: Analysis on the level readiness for self-directed learning among the Diploma students in a private institution.

Table 1: The Levels of level readiness for self-directed learning

\begin{tabular}{lrr}
\hline Level & Frequency & Percentage \\
& & - \\
\hline Low & - & 21.3 \\
Moderate & 29 & 78.7 \\
High & 107 & 100 \\
\hline Total & & \\
\hline
\end{tabular}

Table 1 displays the levels of readiness for self-directed learning as perceived by the Diploma students in of the private institutions in Kuala Lumpur. The findings revealed that majority of respondents that is, $81.5 \%$ (128) perceived that the level of readiness for self- directed learning were high and $18.5 \%$ (29) showed moderate readiness for self-directed learning. On the other hand, none of the respondents showed low readiness for selfdirected learning.

Further analysis was conducted to determine mean and standard deviation scores of each of the dimensions in readiness for self-directed learning as shown in Table 2. 
Table 2: Dimensions of SDRLS

\begin{tabular}{lcc}
\hline Self-directed learning readiness & mean & Std dev \\
\hline Informed acceptance of responsibility for one's own learning & 3.5892 & .60696 \\
Ability to use basic study and problem-solving skills & 3.7467 & .52388 \\
Positive orientation to the future & 3.7858 & .54516 \\
Initiative and independence in learning & 3.8793 & .55083 \\
Love of learning & 3.6537 & .53087 \\
Self- concept as an effective learner & 3.8903 & .54663 \\
Openness to learning opportunities & 3.7706 & .53866 \\
creativity & .58893 \\
\hline
\end{tabular}

Mean indicators: low: (less than 1.66); moderate : (1.66-3.33); High: (more than 3.33)

Table 2 reports the mean and standard deviation scores of respondents for eight dimensions of self-directed learning. The mean scores for each domain were arranged in descending order to rank the levels readiness for selfdirected learning of Diploma students in one of the private institutions in Kuala Lumpur. Results show that the respondents perceived that all the eight dimensions were high. For example, the students perceived that their selfconcept as effective learners as effective learner was high, where $m=3.8903$, std dev $=0.54663$. Besides, the respondents their readiness to take initiative and independent in learning were also perceived as high where $\mathrm{m}=$ 3.8793 , std dev $=0.55083$, followed by readiness towards creativity $(m=3.8280$, std dev $=0.58893)$; positive orientation to the future ( $m=3.7858$, std dev= 0.54516$)$; openness to learning opportunities $(m=3.7706$, std-dev= 0.53866 ) and ability to use basic study and problem solving skills, $m=3.3 .7467$, std dev=.52388). However, mean scores for informed acceptance of responsibility for one's own learning showed slightly lower score mean $=3.5892$, std dev $=0.60696$ ) as compared to the other traits.

Objective 2: Analysis of the differences between readiness for SDLRS and gender

Table 2: Independent t-test between readiness for self-directed learning and gender

\begin{tabular}{lcccc}
\hline & Mean & std dev & $\mathrm{t}$ & $\mathrm{p}$ \\
\hline Self-directed learning & & & & \\
Male & 3.9292 & .49208 & 1.944 & 0.05 \\
Female & 3.7306 & .47138 & & \\
& & & & \\
\hline
\end{tabular}

Based on the independent t-test shown in table 2, there were significant differences between readiness for selfdirected learning and gender; where $t=1.944, p=0.05$ ). Therefore, the result indicates that the males students' readiness for self-directed learning were higher than their female counterparts. 
Objective 3: Analysis of the differences between readiness for self-directed learning and locations

Table 3: ANOVA analysis on the differences between readiness for self-directed learning and locations

\begin{tabular}{lcccc}
\hline & Sum of squares & df & F & sig value \\
\hline Between groups & .185 & 2 & .411 & .664 \\
Within groups & 29.457 & 131 & & \\
Total & 29.642 & 133 & & \\
\hline
\end{tabular}

Based on the ANOVA analysis shown in table 3, there were no significant differences between readiness for selfdirected learning and locations; where $F$ value $=.411, p=0.664$ ). Therefore, the result indicates that the respondents' hometown whether they came from urban, semi- urban or rural did not show any significant readiness for self- directed learning.

Objective 4: To examine the association between readiness for self-directed learning and level academic achievement among the Diploma students in a private institution

Table 4: Cross tabulation analysis on the association between readiness self-directed learning and level academic achievement

\begin{tabular}{llll}
\hline CGPA & SDL & SDL & SDL \\
\hline & Low(n) & Moderate $(\mathrm{n})$ & High(n) \\
\cline { 2 - 4 } Low (less than 2.50) & - & 1 & 2 \\
Moderate low (2.50-3.00) & - & 5 & 22 \\
Moderate high (3.01-3.50) & - & 13 & 43 \\
High( more than 3.50) & - & 10 & 40 \\
\hline Total & & 29 & 107 \\
\hline
\end{tabular}

Chi-square $=0.556, p$ value $=0.906$

Table 4 depicts a crosstab analysis on the association between readiness for self-directed learning and levels of academic achievement among the diploma students in a private institution. On the whole, the result showed that there was no association between SDLRS and academic achievement where chi-square value was $0.566, p=0.906$. Nevertheless, based on descriptive statistics, the finding reveals that the higher the level of academic achievement of the students, the higher their level of readiness for self-directed learning. For instance, 40 students who score high CGPA that is above 3.50 displayed a high level of readiness for self-directed learning as compared to 10 of students with moderate high CGPA displayed a moderate level of self-directed learning. This is followed by 43 students who scores moderately high CGPA that is between 3.01-3.50 also displayed a high level of readiness for self-directed learning as compared to 13 students with moderate high CGPA displayed a moderate level of selfdirected learning.

\section{Discussions and conclusions}

The study was intended to examine the level of readiness for self-directed learning among students in one of the private college institutions. Besides, this study was to examine the association between SDLRS and demographic variables of the respondents. Hence, the findings have drawn three main conclusions. Firstly, the result depicts that majority of the respondents perceived that their level of readiness for SDL was high. This finding is consistent with 
the study was done by Prabjandee \& Inthachot, (2013) and Yuan et al., (2012). Apart from that, each dimension of SDLRS has high mean scores indicating positive towards readiness SDL. Among the highest mean scores on the eight dimensions of SDLRS were self-concept as an effective learner, initiative, and independence in learning and creativity. This could be implied that these college students are capable of setting their learning goals and able to make decisions. It also reflects on respondents' attitudes, values, skills and personality characteristics supportive of self-direction in learning were high. In this sense, Guglielmino (1977) stated that qualities of SDLRS include traits such as initiative, independence, and persistence in learning. Furthermore, Guglielmino (1977) mentioned that learner who has SDLR tends to enjoy learning, goal-oriented and consider problems as challenges. Parallel, Brockett \& Hiemstra (1991) claimed that learners with a high level of SDL ability are self-motivated and able to employ learning resources to solve problems in their learning tasks. Secondly, the finding showed that there was a significant difference between SDLR and gender. This result was congruent with the study was was done by Osman (2015); Grover and Miller (2014) and Derick et al (2007). In this study, the result indicated that the male students were more ready for SDL than their female counterparts. However, Osman (2015) who did a study on 334 first-year Engineering students found that majority of the male respondents were not ready for SDL. He claimed that these students were still at early stages of their university life and thus immediate and systematic guides could unleash the positive attitude. Thirdly, the finding revealed that there was no association between SDLRS and academic achievement. However, based on the descriptive data, it is interesting to note that higher achiever students were more ready than the average or the weak students. The result is in line with the study done by Abraham et al (2011) where they found that high achievers had high scores for all the dimensions of SDLRS. Nevertheless, Abraham et al (2011) suggested that the even though learners had a desire for learning and ability of self-control, learners still need to be supported in self-management skills.

The findings suggest some practical implications for lecturers, educators and educational providers especially in the provision of higher learning institutions. Firstly, the findings have contributed to a better understanding on learners' SDLRS in tertiary education. Guglielmino (1978) noted that high SDRLS reflects that learner can implement own learning successfully as compared to average students who are not fully competent in handling the learning process. She further claimed that weaker students are more prone to traditional learning and lectures and lack of ability to conduct their own learning. Chen (2011) also implied the same where he said that students who have high SDL inclination are much easier to achieve SDL as compared to the weaker ones. On that note, Mahboobe Farahani (2014) hinted that gaining awareness of learners' readiness for SDL can be one of the factors towards reducing the mismatch between educators' expectation and learners' needs. Secondly, there is also a need to retrain teachers or lecturers to change their beliefs and conceptions from considering learning as a process of depositing information given in classes or assignments to viewing learning as a process of promoting critical and creative thinking and emancipatory learning. In this context, Smyth (1993) suggests change is workable if teacher engages in reflective practices. In this aspects, educational providers should plan, design curriculum and instructional strategies that could facilitate learners' own learning. They should act as facilitators rather than spoonfeeding information to the students. They should encourage activities that could stimulate students to express their thoughts and minds and to be creative and innovative. Hence, alternative curriculum should include more of case studies, problem base learning, role play or student-led seminar. This type of learning could enhance learner critical thinking and analytical judgment. Therefore, as students move away from teacher-centre approach to a more student-centered strategy, hence learning become a collaborative process where both educators and learners gain meaningful experiences and better positive relationship. Apart from this, as suggested by Norshidah et al (2013) the learning assessment should not only focus on a grade based learning outcome but to shift to skills and competency based learning outcomes.

In conclusion, the concept of teaching and learning especially in the 21century needs to be re-looked. In today's current knowledge economy environment, SDL capabilities become critical than ever. Hence, in order for the education system to be relevant and competitive, the higher learning institutions need to re-consider bold actions towards giving training to learners to become self-directed and autonomous. Furthermore, in order for the nation to instill lifelong learning, schools, universities and learning organizations need to prepare learners to employ in SDL processes. Moreover, graduates with SDL capabilities and skills are one of the best outcomes for an educational provider can offer for the employment market. Nevertheless, there a several limitation constrain in the interpretation 
of the findings. The study only focuses on one private college, therefore, future studies may benefit from exploration on larger sample size. Besides, further studies on longitudinal research methodology would be useful to validate the framework of SDL.

\section{References}

Abraham, R.R., Murray Fisher, Asha Kamath, M . T. Aizan Izzati, Saidatul Nabila, and Nik Nur Atikah (2011) Exploring first-year undergraduate medical students' self-directed learning readiness to physiology, Adv Physiol Educ 35: 393-395

Adenuga, B. O. (1989) Self-directed learning readiness and learning style preferences of adult learners. Retrospective Theses and Dissertations. Paper 9261.

Benson, P. (2011). Teaching and Researching. Autonomy. Pearson Education Limited

Bolhuis, S. (2003). Towards process-oriented teaching for self-directed lifelong learning: A multidimensional perspective. Learning and Instruction, 13(3), 327-347.

Brockett, R. G. (1985). Methodological and substantive issues in the measurement of self-directed learning readiness. Adult Education Quarterly, $36(1), 15-24$.

Brockett, R. G., \& Hiemstra, R. (1991). Self-direction in adult learning: Perspective on theory, research, and practice. New York, NY: Routledge.

Carson, E.H. (2012) Self-directed learning and academic achievement in secondary online students, Unpublished Doctoral Degree Thesis, The University of Tennessee at Chattanooga Chattanooga, Tennessee

Cazana, A, M., and Schiopcab, B, A. (2014) Self-directed learning, personality traits and academic achievement. Procedia - Social and Behavioral Sciences 127 ( 2014 ) $640-644$

Chou, P.-N., \& Chen, W.-F. (2008). exploratory study of the relationship between self-directed learning and academic performance in a web based learning environment. Online Journal of Distance Learning Administration, 11(1), retrieved from http://www.westga.edu/ distance/ojdla/spring111/chou111.html.

De Bruin, K. (2007). The relationship between personality traits and self-directed learning readiness in higher education students. South African Journal of Higher Education, 21, 228-240.

Denchai Prabjandee, D. \& Inthachot, M. (2013) Self-Directed Learning Readiness of College Students in Thailand Journal of Educational Research and Innovation, Spring, Vol. 2, No. 1

Fahnoe, C. \& Mishra, (2013) Do 21st Century Learning Environments Support Self-Directed Learning? Middle School Students' Response to an Intentionally Designed Learning Environment, Society for Information Technology \& Teacher Education International Conference, Mar 25, 2013 in New Orleans, Louisiana, United States

Flannagan, J.S. (2007). A study of student achievement based on autonomous learning and self-efficacy Unpublished doctoral dissertation, Regent University, Virginia, United States.

Francis, A. and Flaigan, A (2012). Self-Directed Learning and Higher Education Practices: Implications for Student Performance and Engagement Mountain Rise, the International Journal of the Scholarship of Teaching and Learning, Vol 7, Fall.

Freire, P. (1993). Pedagogy of the oppressed. New York: Continuum.

Garrison, D. R. (1997). Self-directed learning: Toward a comprehensive model. Adult Education Quarterly, 48(1), 18-33.

Gibbons, M. (2002). The self-directed learning handbook: Challenging adolescent students to excel. San Francisco, CA: Jossey Bass

Gover, K. S. \& Miller T. (2014) Gender Differences in Self-Directed Learning Practices among Community Members. PAACE Journal of Lifelong Learning, Vol. 23, 2014, 19-31

Grow, G. (199)1 Teaching learners to be self-directed. Adult Education Quarterly 41(3): 125-149 
Guglielmino, L. M. (1977) Development of the Self-Directed Learning Readiness Scale. Unpublished doctoral dissertation, University of Georgia. Dissertation Abstracts International. 38(11a): 6467

Guglielmino, L. M (2013) The Case for Promoting Self-Directed Learning in Formal Educational Institutions, SA-eDUC JOURNAL Volume 10, Number 2 October.

Guglielmino, L. M., \& Guglielmino, P. J. (2008). Information of the Self-Directed Learning Readiness Scale/Learning Preference Assessment. Retrieved September 19, 2008, from www.guglielmino734.com

Hambur, S., Rowe, K., \& Tu Luc, L. (2002). Graduate skills assessment: Stage one validity study. Canberra ACT: Australian Council for Educational Research of the Commonwealth Department of Education Science and Training

Harvey, B. J., Rothman, A. I., \& Frecker, R. C. (2003). Effect of an undergraduate medical curriculum on students' self-directed learning. Academic Medicine, 78(12), 1259-1265.

Harvey, B. J., Rothman, A. I., \& Frecker, R. C. (2006). A confirmatory factor analysis of the Oddi Continuing Learning Inventory. Adult Education Quarterly, 56(3), 188-200.

Hiemstra, R. (2004). Self-directed learning lexicon. International Journal of Self-Directed Learning, 1, 1-6.

Hiemstra, R. (2004).Self---directed learning lexicon. International journal of self-directed learning,1(2),1-6. Retrieved fromhttp://www.sdl global.com/IJSDL/IJSDL1.2---2004.pdf

Hsu, Y. C., \& Shiue, Y. M. (2005). The effect of self-directed learning readiness on achievement comparing face-to-face and two-way distance learning instruction. International Journal of Instructional Media, 32 (2), 143-155.

Knowles, M. (1975). Self-directed learning: A guide for learners and teachers. New York: Association Press.

Long, H. B. (1989). Self-directed learning: Emerging theory and practice. In H. Long (Ed.), Self-directed learning: Emerging theory and practice . Oklahoma Research Center for Continuing Professional and Higher Education

Long, H.B. (1990). Psychological control in self-directed learning. International Journal of Lifelong Education, 9(4), 331-38.

Long. H.B. (1991). Challenges in the study and practice of self-directed learning. In H. B. Long\& Associates, Self-directed learning: Consensus and conflict. Oklahoma Research Center for Continuing Professional and Higher Education

Lounsbury, J. W., Levy, J. J., Park, S.H., Gibson, L. W., \& Smith, R. (2009). An investigation of the construct validity of the personality trait of selfdirected learning. Learning \& Individual Differences, 19, 411-418.

Mahboobe Farahani (2014) From Spoon Feeding to Self-Feeding: Are Iranian EFL Learners Ready to Take Charge of their Own Learning? Electronic Journal of Foreign Language Teaching, Vol. 11, No. 1, pp. 98-115

Merriam,S., Caffarella, R., \& Baumgartner, L. 2007. Learning in adulthood (3rd ed.) San Francisco: Jossey-Bass

$\mathrm{Ng}, \mathrm{W}$. (2008). Self-directed learning with web-based sites: How well do students' perceptions and thinking match with their teachers? Teaching Science: The Journal of the Australian Science Teachers Association, June 1, 24-30.

Norshidah Nordin, Rohaya Abdul Wahab, Nadia Ainuddin Dahlan (2013) Approaches to Learning among Trainee Teachers: Malaysian Experiences, Asia Pacific International Conference on Environment-Behavior Studies University of Westminster, London, UK, 6-8 September

O'Kell, S. P. (1988) A study of the relationships between learning style, readiness for self-directed learning and teaching preference of learner nurses in one health district. Nurse Education Today 8: 197-204

Oddi, L. F. (1984). Development of an instrument to measure self-directed continuing learning (Doctoral Dissertation, Northern Illinois University). Dissertation Abstracts International, 67(01A), 70.

Oddi, L. F. (1986). Development and validation of an instrument to identify self-directed continuing learners. Adult Education Quarterly, 36, 97107.

Oddi, L. F. (1987). Perspectives on self-directed learning. Adult Education Quarterly, 38, 21-31.

Oliveira, A. L., \& Simoes, A. (2006). Impact of socio-demographic and psychological variables on the self-directedness of higher education students. International Journal of Self-Directed Learning, 3, 1-12. 
Osman, M.H. (2015) Ready or not: students with self-directed learning? Journal of Engineering Science and Technology. Special Issue on UKM Teaching and Learning Congress 2013, June (2015) 84 - 90

Pachnowski, L. M., \& Jurczyk, J. P. (2000). Correlating self-directed learning with distance learning success. Paper presented at the Annual Meeting of the Eastern Educational Research Association, Clearwater, FL.

Ponton, M., Derrick, M. G., \& Carr, P. B. (2005). The relationship between resourcefulness and persistence in adult autonomous learning. Adult Education Quarterly, 55(2), 116-128.

Roberson D. N. J. \& Merriam S. B. (2005).The Self-Directed Learning Process of Older, Rural Adults. Adult Education Quarterly, (55) 4. $269-287$.

Robertson, M., Line, M., Jones, S., \& Thomas, S. (2000). International students learning environments and perceptions: A case study using the Delphi Technique. Higher Education Research and Development, 19(1), 89-102.

Shepard, L. A. (2000). The role of assessment in a learning culture. Educational Leadership, 29(7), 4-14.

Siti Akmar Abu Samah, Kamaruzaman Jusoff \& Abu Daud Silong (2009) Does Spoon-feeding Impede Independent Learning? Canadian Social Science, Vol. 5 No.3

Slaughter, R. (2009). Experience in the Doctor of Pharmacy Program at Wayne State University increases students' readiness for self-directed learning. Poster session presented at the annual conference of the American Association of Colleges of Pharmacy, Boston, MA.

Smyth, J. (1993). Reflective practice in teacher education. Australian Journal of teacher

Education, 18(1), Article 2.

Teo, T., Tan, S. C., Lee, C. B., Chai, C. S., Koh, J. H. L., Chen, W. L., et al. (2010). The self directed learning with technology scale (SDLTS) for young students: An initial development and validation. Computers \& Education, 55(4), 1764-1771

Thanh Thi Hong Pham \& Renshaw (2013) How To Enable Asian Teachers To Empower Students To Adopt Student-Centred Learning, Australian Journal of Teacher Education, Volume 38, Issue

Thorpe, M. (2005). The impact of ICT on lifelong learning. In C. McIntosh, Z. Varoglu (Eds.), Lifelong Learning and Distance Higher Education. Commonwealth of Learning/UNESCO Publishing, 23-32.

Tough, A. M. (1967). Learning without a teacher: A study of tasks and assistance during adult self-teaching projects. Toronto, Canada: The Ontario Institute for Studies in Education.

Yuan, H. B., Williams, B. A., Fang, J. B., \& Pang, D. (2012). Chinese baccalaureate nursing students' readiness for self---directed learning Nurse Education Today, 32(4), 427-431. 